\title{
Recent Updates and Advances in Winiwarter-Buerger Disease (Thromboangiitis Obliterans): Biomolecular Mechanisms, Diagnostics and Clinical Consequences
}

\author{
Bahare Fazeli ${ }^{1,2,+} \oplus$, Daniela Ligi ${ }^{3,+} \oplus$, Shayan Keramat ${ }^{4}$, Rosanna Maniscalco ${ }^{3}$, Hiva Sharebiani ${ }^{1}$ \\ and Ferdinando Mannello ${ }^{3, *(1)}$ \\ 1 Immunology Research Center, Inflammation and Inflammatory Diseases Division, School of Medicine, \\ Mashhad University of Medical Science, Mashhad 9177948564, Iran; fazelib@mums.ac.ir (B.F.); \\ hivasharebiani@yahoo.com (H.S.) \\ 2 Vascular Independent Research and Education, European Organization, 20157 Milan, Italy \\ 3 Unit of Clinical Biochemistry, Department of Biomolecular Sciences, Section of Biochemistry and Biotechnology, \\ University “Carlo Bo” of Urbino, 61029 Urbino, Italy; daniela.ligi@uniurb.it (D.L.); \\ r.maniscalco@campus.uniurb.it (R.M.) \\ 4 Hematology Department, Faculty of Medicine, Mashhad University of Medical Science, Mashhad 9177948564, Iran; \\ shayan.sk1993@gmail.com \\ * Correspondence: ferdinando.mannello@uniurb.it \\ + These authors contributed equally to this work.
}

\section{check for} updates

Citation: Fazeli, B.; Ligi, D.; Keramat, S.; Maniscalco, R.; Sharebiani, H.; Mannello, F. Recent Updates and Advances in Winiwarter-Buerger Disease (Thromboangiitis Obliterans): Biomolecular Mechanisms, Diagnostics and Clinical Consequences. Diagnostics 2021, 11, 1736. https://doi.org/10.3390/ diagnostics11101736

Academic Editor: Paolo Zamboni

Received: 16 July 2021

Accepted: 14 August 2021

Published: 22 September 2021

Publisher's Note: MDPI stays neutral with regard to jurisdictional claims in published maps and institutional affiliations.

Copyright: (c) 2021 by the authors. Licensee MDPI, Basel, Switzerland. This article is an open access article distributed under the terms and conditions of the Creative Commons Attribution (CC BY) license (https:// creativecommons.org/licenses/by/ $4.0 /)$.
Abstract: Thromboangiitis obliterans (TAO) or Buerger's disease is a segmental inflammatory, thrombotic occlusive peripheral vascular disease with unknown aetiology that usually involves the medium and small-sized vessels of young male smokers. Due to its unknown aetiology and similarities with atherosclerosis and vasculitis, TAO diagnosis is still challenging. We aimed to review the status of biomolecular and laboratory para-clinical markers in TAO compared to atherosclerosis and vasculitis. We reported that, although some biomarkers might be common in TAO, atherosclerosis, and vasculitis, each disease occurs through a different pathway and, to our knowledge, there is no specific and definitive marker for differentiating TAO from atherosclerosis or vasculitis. Our review highlighted that pro-inflammatory and cell-mediated immunity cytokines, IL-33, HMGB1, neopterin, MMPs, ICAM1, complement components, fibrinogen, oxidative stress, NO levels, eNOS polymorphism, adrenalin and noradrenalin, lead, cadmium, and homocysteine are common markers. Nitric oxide, MPV, TLRs, MDA, ox-LDL, sST2, antioxidant system, autoantibodies, and type of infection are differential markers, whereas platelet and leukocyte count, haemoglobin, lipid profile, CRP, ESR, FBS, creatinine, d-dimer, hypercoagulation activity, as well as protein $\mathrm{C}$ and $\mathrm{S}$ are controversial markers. Finally, our study proposed diagnostic panels for laboratory differential diagnosis to be considered at first and in more advanced stages.

Keywords: Buerger's disease; Thromboangiitis obliterans; oxidative stress; antioxidant capacity; blood count; lipid profile; cytokines; autoantibodies; hypercoagulation; infection

\section{Introduction}

Thromboangiitis obliterans (TAO) or Buerger's disease is a segmental inflammatory, thrombotic occlusive peripheral vascular disease with unknown aetiology that usually involves the medium and small-sized vessels of young male smokers [1]. TAO has geographical distribution, and it is more common in the Middle East, Far East, South-East Asia, Eastern Europe, and South America [2]. However, there is still no explanation for the geographic distribution of TAO.

Due to the unknown aetiology of TAO, its diagnosis is still challenging. Pathology of the acute lesions is pathognomonic for TAO diagnosis [3]. However, the pathology study is possible on amputees. Even biopsies of superficial thrombophlebitis are not recommended 
in TAO patients due to the poor circulation of the limb and the risk of developing chronic ulcers at the site of biopsy.

Moreover, until recently, TAO could neither be suggested nor be diagnosed according to biological markers.

Therefore, several diagnostic criteria have been suggested for TAO diagnosis. In particular, one of the most acceptable in the countries where TAO is common is Shionoya's clinical criteria [4]. These criteria refer to the clinical manifestation of the disease and the absence of atherosclerotic risk factors except for smoking (e.g., hyperlipidemia and diabetes). Since TAO is usually registered in low socioeconomic classes or countries with social, economic, or political crises [5], Shionoya's clinical criteria are eligible for these patients to escape the considerable costs of imaging. However, Shionoya suggested these criteria in 1988, whilst the cut-off points for the definition of hyperlipidemia and diabetes in the 1980s were different from their current cut off points. Several biomarkers of atherosclerosis have been introduced and studied during the last decades, and some of them, like hyper-homocysteinemia, have been reported in both atherosclerosis and TAO $[6,7]$.

However, some angiologists prefer to diagnose TAO by excluding other types of vasculitis and hypercoagulable states based on laboratory para-clinical findings alongside the imaging [8].

In this paper, we will review the status of studied biomolecular and laboratory paraclinical markers in TAO compared to atherosclerosis, vasculitis, and hypercoagulopathies.

\section{Complete Blood Count (CBC)}

Several studies reported anaemia, most commonly normochromic and normocytic type, in about $40 \%$ of TAO patients, particularly during the acute exacerbation of the disease $[9,10]$. Notably, a significant inverse correlation between haemoglobin $(\mathrm{Hb})$ level and duration of smoking has been reported in TAO patients, which is not anticipated because a high $\mathrm{Hb}$ level would be expected in long-term, heavy smokers [9]. Moreover, one of these studies demonstrated that $\mathrm{Hb}$ from TAO patients had decreased over a short period of time, with a trend that did not resemble trends found in chronic anaemia, as observed in other types of vasculitis [9].

In another study, although the indirect Coombs test was positive in $70 \%$ of the TAO patients with high levels of LDH (Lactate dehydrogenase) and AST (Aspartate aminotransferase) and normal levels of ALT (Alanine aminotransferase), the definitive diagnosis of hemolytic anaemia was not confirmed, because of the normal level of bilirubin as well as the normal or high level of haptoglobin [10].

Although normal platelet count has been reported in TAO patients, thrombocytosis and thrombocytopenia have been reported in $6.4 \%$ and $2.9 \%$ of the patients, respectively [9]. Notably, thrombocytosis has been observed in those patients who underwent major amputation. Leukocytosis and neutrophilia have also been reported in TAO patients during the acute exacerbation of the disease [9].

Notably, leukocytosis, thrombocytosis, and normochromic and normocytic anaemia are usually seen in systemic vasculitis [11,12]. Moreover, leukopenia and thrombocytopenia are more common in vasculitis, whilst anaemia is also observed in systemic vasculitis.

Increased platelet response to serotonin has been described in TAO patients compared to healthy male controls. About half of the controls in this study were smokers [13].

In contrast to atherosclerosis or vasculitis, low mean platelet volume (MPV) has been observed in TAO patients [14]. MPV is an indicator of platelet activation, and there is strong evidence indicating that MPV is an important variable and that larger platelets have a higher thrombogenicity. It is implicated that the severe inflammatory condition has been associated with low MPV, which increases with anti-inflammatory therapy [14]. Interestingly, it has been reported that other metabolic disorders, such as high cholesterol and diabetes, have an association with increased MPV, and this could indicate a link between increased MPV and atherosclerosis [15]. 
The disease activity and severity in some vasculitis, such as Behcet's disease, has been associated with higher MPV [16], and in some other vasculitis, such as Systemic Lupus Erythematous (SLE), has been associated with lower MPV [17].

A summary of the main findings is reported in Table 1.

Table 1. Summary of the main findings on Complete Blood Count (CBC).

\begin{tabular}{|c|c|c|c|}
\hline CBC & TAO & Atherosclerosis & Vasculitis \\
\hline Anaemia & Has been reported & Independent factor & Common \\
\hline Platelet count & $\begin{array}{c}\text { Mostly normal; } \\
\text { rarely high in patients } \\
\text { with major } \\
\text { amputation or low } \\
\text { due to consumption } \\
\text { in thrombosis } \\
\text { formation }\end{array}$ & Normal & $\begin{array}{c}\text { Thrombocytopenia is } \\
\text { common }\end{array}$ \\
\hline Leukocyte count & $\begin{array}{l}\text { Leukocytosis with } \\
\text { neutrophilia has been } \\
\text { reported }\end{array}$ & $\begin{array}{c}\text { Mostly high and } \\
\text { considered as a risk } \\
\text { factor }\end{array}$ & $\begin{array}{l}\text { Leukopenia is } \\
\text { common }\end{array}$ \\
\hline MPV & Mostly low & $\begin{array}{l}\text { Mostly high due to } \\
\text { hyperactivation }\end{array}$ & Mostly normal \\
\hline
\end{tabular}

\section{Biochemical Markers}

\subsection{Lipid Profile}

For years, TAO had been misunderstood as a kind of presenile atherosclerosis obliterans $[18,19]$. However, after the recognition of TAO as an individual disease, excluding the risk factors of atherosclerosis (e.g., diabetes and hyperlipidemia) became a part of the diagnostic criteria of TAO [4].

Notably, it seems that long term smoking influences the lipid profile, with higher cholesterol, higher low-density lipoprotein (LDL), and lower high-density lipoprotein (HDL) [20].

The serum cholesterol level in TAO patients has been reported ranging from $157 \mathrm{mg} / \mathrm{dL}$ to $225 \mathrm{mg} / \mathrm{dL}$, whereas LDL and HDL levels were 94-112 mg/dL and 34-54 mg/dL, respectively [21-23].

In 2013, Hus et al. reported significantly higher cholesterol serum levels in cigarettesmoking TAO patients compared with non-smoking ones. However, regarding the serum level of cholesterol in these patients, it has not been reported whether it was in the normal range [21].

It is still unknown whether a low level of total cholesterol in TAO patients is due to any impairment in mitochondria function or because of the bias of excluding hyperlipidemic patients from TAO diagnosis.

\subsection{Blood Sugar}

During the 1930s, it was noticed that patients with TAO diagnosis did not have diabetes [24,25]. Nowadays, hyperlipidemia and diabetes are also known as excluding factors for a TAO diagnosis [4]. Even if a patient with a TAO diagnosis develops diabetes years after the initial diagnosis of TAO, the TAO diagnosis would be ruled out retroactively. In 1992, Papa et al. suggested not to rule out the initial diagnosis of TAO according to typical clinical manifestation and angiography if the patient develops diabetes years after TAO diagnosis [26].

In addition, a few cases of diabetes in patients with TAO diagnosis, confirmed by pathology without any atherosclerotic plaque, have been reported. Notably, the patients' fast blood sugar (FBS) was not more than $113 \mathrm{mg} / \mathrm{dL}[21,27,28]$.

According to pathological studies of below-knee amputees of two diabetic cases with a diagnosis of PAD (peripheral artery disease), it has been reported that the diagnosis 
was TAO because of inflammatory thrombosis and the absence of atherosclerotic plaques. However, they had excluded those cases from the TAO group because of their being diabetic $[22,29]$.

\subsection{Oxidative Stress}

Several studies indicate that oxidative stress promotes endothelial cell dysfunction and can directly influence vascular tone by decreasing nitric oxide (NO) bioavailability [30]. This condition activates a vicious circle because a malfunctioned vascular endothelium is a source of oxidative stress by itself. Moreover, besides vascular endothelium, it has been demonstrated that vascular adventitia is a major producer of oxidative stress, particularly in response to hypoxic stresses, where it has a key role in regulating vascular tone by targeting NO bioavailability [31]. It seems that the known risk factors of cardiovascular disease, including smoking, diabetes, and hyperlipidemia, lead to higher oxidative stress [32,33].

Notably, oxidative stress seems significantly higher in TAO patients than smoking habit-matched controls [34]. This means that other factors besides smoking are responsible for high oxidative stress in TAO patients. A low serum level of NO metabolites in TAO has been reported compared to smoking controls, which might be one reason for high oxidative stress in TAO. Nevertheless, it is not well defined if the low NO level is responsible for high oxidative stress in TAO or secondary to high oxidative stress [35]. Moreover, it has been reported that polymorphisms in the promoter region of nitric oxide synthase correlate with major amputation in TAO patients [36]. Interestingly, besides NO alterations in TAO patients, it has been demonstrated that the level of heme-oxygenase 1 (HMOX1), which is implicated in maintaining the backup of nitric oxide, is intact and significantly higher in TAO patients compared to controls [37].

Notably, a higher level of nitric oxide has been demonstrated in patients with coronary artery disease [38]. Moreover, increased NO production has been reported in some autoimmune conditions, including rheumatoid arthritis, systemic lupus erythematosus, and Behcet's disease [39-42].

oxLDL, malondialdehyde (MDA), carbonyl protein (PC), superoxide dismutase (SOD), glutathione reductase (GR), myeloperoxidase (MPO), and coenzyme Q10 (co-Q10) are also important markers that play a role in oxidative stress status [43-45]. Interestingly, in 2010, Arslan et al. found that oxLDL was higher in patients with TAO than atherosclerosis [46].

Recently, a significantly lower level of MDA and SOD has been reported in TAO patients compared to smoker controls [35]. Notably, a higher level of MDA and SOD has been reported in atherosclerosis [33]. A higher level of MDA in SLE without any significant association with the disease activity has also been reported [47]. However, SOD activity has been reported as normal to significantly lower in SLE patients compared to controls $[47,48]$.

No significant difference between PC, GR, and MPO levels has been demonstrated in TAO vs. controls [35]. However, a higher level of PC has been reported in both atherosclerosis and SLE [49,50].

Moreover, a higher level of glutathione reductase in atherosclerosis has been demonstrated, whilst no significant difference in GR level has been reported in SLE [51,52].

Further, a higher level of MPO in atherosclerosis and the active phase of several vasculitis, including Behcet's disease has been reported [53,54].

Interestingly, the serum level of CoQ10 has been reported to be significantly higher in TAO compared to controls. The high levels of CoQ10 in TAO patients might be responsible for a lower level of MDA by increasing its catabolism [35]. Lower levels of CoQ10 have been noticed in atherosclerosis and in some autoimmune diseases $[55,56]$.

\subsection{Creatinine}

Elevated serum creatinine concentration was proposed to be a marker for increased risk of cardiovascular disease mortality [57]. There are a few case reports about the involvement of renal arteries in TAO and consequently higher creatinine level [58]. Serum 
creatinine level in systemic vasculitis could also be high according to the involvement of the kidneys [59].

\subsection{Catecholamine Concentration}

Few studies have been performed to evaluate the level of catecholamines in TAO patients, either in group studies or in case reports. They showed that the level of catecholamines in patients with TAO increases. Of course, the effect of smoking on increasing levels of catecholamines has also been clearly shown, but Roncon-Albuquerque et al. demonstrated that in patients with TAO, cigarette smoking had different effects in plasma catecholamines compared to controls $[27,60]$. According to their results, smoking decreased noradrenalin in controls but increased in TAO patients. Although in TAO patients with sympathectomy smoking did not significantly change noradrenalin, there was a pronounced fall in adrenalin [60].

Compared with TAO, increased levels of catecholamines have also been reported in patients with atherosclerosis. Bauch et al. have shown significantly high plasma concentrations of epinephrine and norepinephrine in patients with coronary artery disease (CAD), and they considered these results as a hypothesis revealing that catecholamines may play a role in the development and subsequent complications of atherosclerosis [61]. In vasculitis, the association of catecholamines with the disease has been clearly investigated, and the results have led to the development of a group of vasculitis called Catecholamine-induced vasculitis. Catecholamine-induced vasculitis is well known. Sarathi et al. [62], studying the relationship between catecholamines and vasculitis, found a correlation between pheochromocytoma and aortoarteritis, and thus demonstrated the essential role of catecholamines in the development of aortoarteritis. This aspect has been recently confirmed by Toutai et al., who stated that high catecholamine levels may have a role in the etiopathogenesis of aortoarteritis in these patients [63].

\subsection{Heavy Metals}

Food, smoking, and air pollution are the major sources of lead, cadmium, and other toxic heavy metals such as arsenic [64]. Although the cardiovascular consequences of metal toxicity have not been published widely enough, it has been demonstrated that heavy metals induce vascular dysfunction by inducing high oxidative stress, reducing endothelial nitric oxide synthase activities, and enhancing the phosphorylation of myosin light chain kinases [65].

Various studies indicated that heavy metals in tobacco and other sources might be one of the causative factors for TAO development. This is particularly true for cadmium, lead, and arsenic [66].

An association between lead and cardiovascular disease has been recognized and considered an established risk factor for oxidative stress, inflammation, and the triggering event of atherosclerosis [67].

Moreover, the role of cadmium as a cardiovascular disease risk factor, especially for coronary disease, has been indicated [68]. In addition, the role of heavy metals in the formation of vasculitis has been reported [69]. Albert et al., studying Wegener's granulomatosis (WG), found that mercury and lead have been associated with the etiopathogenesis of WG [70]. On the other hand, it has been discussed that lead and its possible proinflammatory action, including the influence on pro-inflammatory cytokine production and its effective role in causing vasculitis, can be considered [71].

\subsection{Bilirubin}

Generally, abnormal bilirubin levels are considered a sign of hepatic disorders. Although bilirubin has long been believed to be an excretory metabolite, one of the most critical studies on the association between bilirubin and cardiovascular system pointed to the effective role of bilirubin in preventing atherosclerosis [72]. In 1994, Schwertner et al. found that lower bilirubin levels were significantly associated with an increased risk of coro- 
nary artery disease [73]. On the other hand, it was observed that increasing bilirubin levels in cardiovascular patients are associated with a decreased risk of atherosclerosis [72-74]. In $\mathrm{TAO}$, bilirubin has been reported in normal range [10]. In vasculitis, especially autoimmune vasculitis, the bilirubin can increase under the influence of autoimmune hemolytic anaemia (AIHA) [75,76].

Tovoli et al. also observed the increase of bilirubin due to autoimmune liver disorders (AILD) in small-vessel vasculitis [77]. Nevertheless, bilirubin plays an essential role in other vasculitis as a diagnostic marker, such as Behcet's disease, where a decrease in bilirubin can be observed, according to Koca et al. [78].

\subsection{Liver Function Test}

The evaluation of liver function tests (LFT) provides many indications and is mainly performed in systemic diseases as a prognostic indicator. Notably, the patient's age can influence the results of AST as a positive correlation and ALT as a negative correlation [79].

Higher levels of AST and normal levels of ALT have been reported in young TAO patients [75].

However, a higher level of ALT, as a marker of fatty liver and increasing the risk of insulin resistance, seems a risk factor for atherosclerosis [80].

Moreover, higher levels of liver enzymes have been noticed in several autoimmunities [77].

A summary of the main findings is reported in Table 2.

Table 2. Summary of the main findings on biochemical markers.

\begin{tabular}{|c|c|c|c|}
\hline Biochemical Markers & TAO & Atherosclerosis & Vasculitis \\
\hline Fast Blood Sugar & $\begin{array}{l}\text { Normal to slightly high } \\
\quad(<120 \mathrm{mg} / \mathrm{dL})\end{array}$ & Normal to high & Normal \\
\hline Cholesterol & Normal to slightly high & High & Normal \\
\hline LDL & Normal to slightly high & High & Normal \\
\hline HDL & Low to normal & Low & Normal \\
\hline Total oxidative stress & $\begin{array}{l}\text { High with intact antioxidant } \\
\text { capacity }\end{array}$ & $\begin{array}{l}\text { High with impaired } \\
\text { antioxidant capacity }\end{array}$ & $\begin{array}{l}\text { High in several autoimmune } \\
\text { vasculitis }\end{array}$ \\
\hline MDA & Normal & High & High \\
\hline $\mathrm{NO}$ & $\begin{array}{l}\text { Low with eNOS } \\
\text { polymorphism }\end{array}$ & High & $\begin{array}{c}\text { Low with eNOS } \\
\text { polymorphism } \\
\text { High in SLE and RA with } \\
\text { iNOS high expression }\end{array}$ \\
\hline Creatinine & High & Normal to slightly high & $\begin{array}{c}\text { Slightly high in } \\
\text { Anca-Associated Vasculitis } \\
\text { (AAV) and normal in Behcet's } \\
\text { disease }\end{array}$ \\
\hline Heavy metals & $\begin{array}{l}\text { High level of lead, cadmium, } \\
\text { arsenic }\end{array}$ & High level of lead, cadmium & $\begin{array}{l}\text { High level of lead and is } \\
\text { related to mercury in } \\
\text { Wegener's granulomatosis }\end{array}$ \\
\hline Catecholamine concentration & $\begin{array}{l}\text { High level of adrenalin and } \\
\text { noradrenalin }\end{array}$ & $\begin{array}{l}\text { High level of epinephrine and } \\
\text { norepinephrine }\end{array}$ & $\begin{array}{c}\text { High especially in } \\
\text { catecholamine-induced } \\
\text { vasculitis }\end{array}$ \\
\hline Bilirubin & Normal & $\begin{array}{l}\text { Low to High } \\
\text { High levels associated with } \\
\text { good prognosis }\end{array}$ & $\begin{array}{l}\text { High in AILD with small } \\
\text { vessel vasculitisLow in } \\
\text { Behcet's disease }\end{array}$ \\
\hline $\begin{array}{l}\text { Hepatic function test } \\
\text { (AST and ALT) }\end{array}$ & High AST with normal ALT & $\begin{array}{l}\text { Mostly high level is related to } \\
\text { fatty liver }\end{array}$ & $\begin{array}{l}\text { High in liver involvement } \\
\text { related to AAV and } \\
\text { Rheumatoid Arthritis }\end{array}$ \\
\hline
\end{tabular}




\section{Inflammatory Biomarkers}

\subsection{C-Reactive Protein and Erythrocyte Sedimentation Rate}

C-reactive protein (CRP) and erythrocyte sedimentation rate (ESR) have been usually observed in normal range in TAO patients [30]. Moreover, in some TAO diagnostic criteria, positive ESR and CRP have been considered factors for ruling out TAO diagnosis [81]. However, several studies reported high levels of CRP in TAO patients [75,82]. There is no study on ESR levels in TAO patients.

\subsection{Cytokines}

Although TAO is not known as systemic vasculitis, the serum levels of different cytokines have been evaluated in TAO patients. Significantly higher serum levels of proinflammatory cytokines, including TNF-alpha (TNF- $\alpha$ ), interleukin-1 beta (IL-1 $\beta$ ), and interleukin-6 (IL-6), have been reported in TAO patients compared to controls $[83,84]$. Nevertheless, in the work of Joras et al., the serum level of TNF- $\alpha$ had no significant difference between TAO and controls [85]. Moreover, cytokines of cellular immunity, including interferon-gamma (IFN- $\gamma$ ) and interleukin 12 (IL-12), cytokines of humoral immunity including interleukin 4 (IL-4), interleukin 5 (IL-5), and interleukin 13 (IL-13), have been reported in TAO patients compared to smoker controls [83].

Moreover, high serum levels of IL-17, $-22,-23$, and -33 and low IL-10 have been reported in TAO compared to smoker controls $[14,86,87]$.

The levels of cytokine released and the T-cell mediated immunity in TAO could also be the result of different HLA patterns of expression in TAO patients, as reported by Shapouri-Moghaddam et al. [88].

\subsection{Complement Component}

High levels of $\mathrm{C} 4$ have been reported in patients with a severe form of TAO [89]. Notably, a high serum level of $\mathrm{C} 3$ and $\mathrm{C} 4$ has also been reported in atherosclerosis [89]. However, serum levels of $\mathrm{C} 3$ and $\mathrm{C} 4$ range from low to high according to the type of vasculitis $[90,91]$.

\subsection{Other Inflammatory Mediators}

As a biomarker of cellular immunity, Neopterin has been reported to be significantly higher in the active phase of TAO compared to its quiescent phase and controls [92].

Toll-like receptors (TLRs) are the main components of innate immunity and have an essential role in the pathogenesis of autoimmune and autoinflammatory diseases. Notably, TLR4 has been reported to be significantly lower in the quiescent phase of TAO compared to controls. In patients with active TAO, no difference between the serum level of TLR4 in patients and controls has been found. No changes in serum levels of TLR2 in active and quiescent phase of TAO or between TAO patients and controls have been found [92].

High mobility group box 1 protein (HMGB1), which acts as a pro-inflammatory cytokine, has been reported to be significantly higher in TAO patients than healthy nonsmokers [93]. Moreover, significantly increased intercellular adhesion molecule -1 (ICAM-1) and vascular cell adhesion molecule -1 (VCAM-1), key regulators of vascular permeability, have been demonstrated in TAO patients compared to healthy non-smokers [94,95].

Notably, a significantly high level of matrix metalloproteinase 9 (MMP-9) as a regulator of vascular permeability in TAO patients compared to non-smokers has been reported [93]. Similarly, high levels of different classes of MMPs have been reported in atherosclerosis and vasculitis [96-98].

A summary of the main findings is reported in Table 3. 
Table 3. Summary of the main findings on inflammatory markers.

\begin{tabular}{|c|c|c|c|}
\hline Inflammatory Biomarkers & TAO & Atherosclerosis & Vasculitis \\
\hline ESR & Controversial & $\begin{array}{l}\text { High (usually }>18 \text { and } \\
<30 \mathrm{~mm} / \mathrm{h} \text { ) }\end{array}$ & $\begin{array}{c}\text { Extremely high } \\
(\text { even }>100 \mathrm{~mm} / \mathrm{h})\end{array}$ \\
\hline CRP & Controversial & High (usually >12 mg/L) & $\begin{array}{l}\text { High (usually } 5 \text { to } 15 \mathrm{mg} / \mathrm{L} \text { ) } \\
\text { More than } 25 \mathrm{mg} / \mathrm{L} \text { as a } \\
\text { marker of infection in } \\
\text { vasculitis }\end{array}$ \\
\hline Pro-inflammatory & High level of TNF- $\alpha$, IL-1,IL- 6 & High level of IL-1, IL-6, IL-18 & High level of TNF- $\alpha$, IL-1,IL-6 \\
\hline Th1-related & High level of IL-12 IFN- $\gamma$ & High level of IL-12 & High level of IFN- $\gamma$, IL-12, \\
\hline Th2-related & High level of IL-4, IL-5, IL-13 & High level of IL-4, IL-5 & High level of IL-4, IL-5, IL-13 \\
\hline Th17-related & $\begin{array}{l}\text { High level of IL-17, IL-22, } \\
\text { IL-23, IL-21 }\end{array}$ & $\begin{array}{c}\text { High level of IL-21, IL-22, } \\
\text { IL-23 }\end{array}$ & $\begin{array}{l}\text { High level of IL-23, IL-17, } \\
\text { IL-21 }\end{array}$ \\
\hline Anti-inflammatory & Low level of IL-10 & Low levels of TGF- $\beta$, IL-10 & High level of IL-10 \\
\hline Others & $\begin{array}{l}\text { High level of IL-33 (without } \\
\text { increasing levels of Soluble } \\
\text { suppression of } \\
\text { tumorigenicity-2, sST2) }\end{array}$ & $\begin{array}{l}\text { High level of IL-35, IL-33, } \\
\text { IL-15 }\end{array}$ & $\begin{array}{l}\text { High level of IL-33 (with } \\
\text { increased sST2 level) }\end{array}$ \\
\hline HMGB1 & High & High & High \\
\hline Neopterin & High in the acute phase & High & High \\
\hline TLRs & Low level of TLR4 & High level of TLR4 and TLR2 & High level of TLR4 and TLR5 \\
\hline $\begin{array}{l}\text { Matrix Metalloproteinases } \\
\text { (MMPs) }\end{array}$ & High MMP-9 & $\begin{array}{l}\text { High MMP-1, MMP-2, } \\
\text { MMP-9, MMP-3, MMP-12, } \\
\text { MMP-13 }\end{array}$ & High MMP-2, MMP-9, MMP-3 \\
\hline ICAM1 & High & High & High in AAV, SLE, WG \\
\hline Complement component & $\begin{array}{l}\text { High level of C4 in patients } \\
\text { with severe form of TAO }\end{array}$ & High serum level of C3, C4 & $\begin{array}{l}\text { High C3, C4 levels in immune } \\
\text { complex-mediated vasculitis } \\
\text { are reported while in SLE, C3 } \\
\text { and C4 were decreased }\end{array}$ \\
\hline
\end{tabular}

\section{Autoantibodies}

Until recently, TAO is not known as a systemic vasculitis, and it is still unknown whether it is an autoimmune disorder [86,87]. However, the existence of several autoantibodies in some TAO patients has been reported, including anti-endothelial cell antibody (AECA), anti-elastin, and anti-collagen I and III antibodies [99-102]. In 1998, the presence of antineutrophil cytoplasmic antibodies (ANCA) was reported in patients with TAO [103]. The study found a significantly higher ANCA level in patients with severe clinical manifestations compared to patients with mild disease and controls [104]. However, several further studies have ruled out the presence of ANCA in TAO patients and their association with the disease [105].

In addition, high levels of anti-cardiolipin antibody and anti-Beta2 glycoprotein antibody have been reported in TAO patients [106]. Due to the fluctuation in the levels of these antibodies, the diagnosis of anti-phospholipid syndrome could not be established. However, it seems that TAO patients with high anti-cardiolipin titers tend to be younger and to suffer from a significantly higher rate of major amputations [106].

As reported in Table 4, some autoantibodies have also been described in vasculitis and atherosclerosis [107-110]. 
Table 4. Summary of the main findings on autoantibodies.

\begin{tabular}{cccc}
\hline Autoantibodies & TAO & Atherosclerosis & Vasculitis \\
\hline Anti-Cardiolipin & positive (IgM class) & Negative & positive (mostly IgG class) \\
\hline Anti-dsDNA, ANA & Negative & Negative & Positive in vasculitis such as SLE \\
\hline Anti-beta2 & positive (IgM class) & positive (IgM class) & Not reported \\
\hline AECA & positive & Negative & positive \\
\hline ANCA & negative & Negative & Positive in AAV \\
\hline Lupus anticoagulant & negative & Negative & positive \\
\hline
\end{tabular}

A summary of the main findings is reported in Table 4 .

\section{Thrombogenicity}

Hypercoagulation

Although hypercoagulability has been considered an exclusive factor for TAO diagnosis, several studies have reported thrombogenic risk factors in TAO patients.

For instance, lower clot permeability and prolonged clot lysis time in TAO patients compared to other types of peripheral arterial diseases (PADs) and smoker controls have been reported [111].

Also, increased thrombin formation has been reported in TAO patients [112]. Although a significantly higher level of urokinase-plasminogen activator (uPA) and lower level of plasminogen activator inhibitor I (PAI-1) have been reported in TAO, fibrinolysis seems to be impaired [21,113]. However, another study reported that PAI-1 was expressed along the internal elastic lamina, whereas urokinase-type plasminogen activator and MMP-3 were slightly expressed in intima and media [114].

Interestingly, it seems that D-dimer released from clots is markedly slower in TAO patients compared to other patients with PADs [111,115].

A significantly higher level of fibrinogen in TAO patients compared to patients with other types of PADs or healthy smokers has been reported [111,113].

Protein $\mathrm{C}$ and $\mathrm{S}$ deficiency has been considered as exclusive factors for TAO diagnosis [115]. However, two separate case reports have implied the co-existence of Protein $\mathrm{C}$ and S deficiency with TAO [116]. Moreover, a mutation in factor Leiden $\mathrm{V}$ has been reported in TAO patients via a few case reports. Interestingly, almost all of these case reports have thrombosis in large vessels or deep venous thrombosis, but the histopathology of the amputees was suggestive for TAO [117,118].

Hyperhomocysteinemia has also been reported in TAO patients [119]. Hyperhomocysteinemia can induce thrombogenicity by increasing vascular adhesion molecules and tissue factors, inhibiting fibrinolysis as well as inducing nitric oxide bioavailability impairment and platelet activation [120]. Nevertheless, its level in TAO patients compared to healthy smokers is controversial in different studies. Some studies have considered hyperhomocysteinemia as an independent risk factor for TAO development. However, in other studies, due to the absence of significant differences between homocysteine levels in TAO patients and healthy smokers, hyperhomocysteinemia as a consequence of smoking in TAO patients was not considered an individual risk factor [120,121]. On the contrary, in atherosclerosis, it has been described a normal coagulation profile [122].

On the other hand, in vasculitis, a hypercoagulable profile has been reported in both Behçet syndrome and AAV, in which the main cause is referred to NETosis and endothelial dysfunction, respectively [123]. Furthermore, high levels of d-dimer have been often reported in AAV, SLE, granulomatosis with polyangiitis (GPA), Henoch-Schönlein purpura, and Kawasaki disease [124].

Finally, increased levels of homocysteine have also been reported in atherosclerosis and vasculitis [125,126].

A summary of the main findings is reported in Table 5. 
Table 5. Summary of the main findings on thrombotic factors.

\begin{tabular}{|c|c|c|c|}
\hline Thrombotic Factors & TAO & Atherosclerosis & Vasculitis \\
\hline Hypercoagulation activity & $\begin{array}{l}\text { Mostly considered as normal, } \\
\text { but with increased risk with } \\
\text { Factor } \mathrm{V}_{\text {Leiden }} \text { mutation }\end{array}$ & Normal activity & $\begin{array}{l}\text { Hypercoagulable states } \\
\text { mostly reported in Behçet } \\
\text { syndrome and AAV }\end{array}$ \\
\hline d-dimer & $\begin{array}{l}\text { It has been reported D-dimer } \\
\text { levels are considerably } \\
\text { elevated in patients with TAO }\end{array}$ & High in thrombotic event & $\begin{array}{l}\text { High levels in AAV, SLE, } \\
\text { Granulomatosis with } \\
\text { polyangiitis (GPA) } \\
\text { Henoch-Schönlein purpura, } \\
\text { Kawasaki disease }\end{array}$ \\
\hline Fibrinogen level & High level & High & High in systemic vasculitis \\
\hline Protein C, Protein s & Mostly considered as normal & $\begin{array}{c}\text { Protein } C \text { and Protein } S \\
\text { deficiency has been reported } \\
\text { as a risk factor for aggravation } \\
\text { of atherosclerosis }\end{array}$ & Normal \\
\hline Hyperhomocysteinemia & Has been reported & Has been reported & Has been reported \\
\hline
\end{tabular}

\section{Infection}

The footprint of infectious pathogens in TAO development was suggested early after the disease description by Leo Buerger $[127,128]$. However, until recently, two pathogens attracted the attention: oral bacteria and rickettsial infection. Although the high immunoglobulin titer against oral bacteria and rickettsia has been reported, it is not evaluated in the routine practice for TAO diagnosis $[129,130]$.

A summary of the main findings herein described is reported in Table 6.

Table 6. Summary of the main findings on infection.

\begin{tabular}{|c|c|c|c|}
\hline & TAO & Atherosclerosis & Vasculitis \\
\hline Infection & $\begin{array}{l}\text { Oral bacteria and rickettsial } \\
\text { infection. }\end{array}$ & $\begin{array}{c}\text { Chlamydophila pneumoniae, } \\
\text { Helicobacter pylori, CMV } \\
\text { (Cytomegalovirus) and oral } \\
\text { bacteria }\end{array}$ & $\begin{array}{c}\text { Viral infection (e.g., Human } \\
\text { Immunodeficiency Virus and CMV), } \\
\text { Streptococcus pneumoniae, rickettsia, } \\
\text { Mycobacterium, Staphylococcus } \\
\text { aureus, Chlamydia, Neisseria }\end{array}$ \\
\hline
\end{tabular}

\section{Genetic Background}

Several studies have been conducted on the genetic background of TAO. Although susceptibility to TAO has been suggested to be at least in part controlled by genes involved in innate and adaptive immunity, vascular physiology, platelet function or coagulation pathways, the presence of any particular gene polymorphism is controversial.

One of the most critical limitations of studies on genetic background of TAO is the lack of sufficient sample size due to the rarity of the disease. Obviously, allele frequencies based on small sample sizes will increase the false-positive evidence for linkage [131]. Besides, there is a lack of supporting studies regarding any polymorphism claim for TAO. These limitations make the results of genetic studies on TAO not quite reliable. For instance, several studies have explored HLA typing in TAO since the 1990s [88,132-136]. Although few polymorphisms have been detected to be associated with TAO in each study, the results are quite regional. Besides HLA-DRB1*15, which is a common polymorphism in TAO patients from Iran and India $[88,135]$, and HLA-DRB1*04, which is a common polymorphism in the TAO patients from Japan and Iran $[88,136]$, the rest of the polymorphisms of HLAs in TAO patients have been varied in different regions. Notably, HLA-DRB1*15 has also been reported as a risk factor for PR3-ANCA associated vasculitis in African Americans [137], and HLA-DRB1*04 has been associated with several vasculitis [138-140]. 
No association between HLA-DRB1*15 and atherosclerosis has been reported. However, early cardiovascular events in smokers with HLA-DRB1 ${ }^{*} 04$ have been noticed [141].

Besides HLA typing, several studies on the single nucleotide polymorphism of nitric oxide synthase, endothelin 1 , plasminogen activator inhibitor, platelet receptors, homocysteine, Factor V, prothrombin, and Toll-like receptor 4 and CD14 have been conducted on TAO patients.

However, until recently, among all studied polymorphisms, only two studies had reported the association of eNOS T-786 C polymorphism of endothelial nitric oxide synthase with TAO [36,142]. Interestingly, according to a meta-analysis conducted in 2015, there was no association between eNOS T-786 C polymorphism and vasculitis [143]. However, the association between eNOS T-786C and atherosclerosis seems to be controversial $[144,145]$.

\section{Discussion}

Until recently, the aetiology and even TAO classification as a kind of PAD or small and medium-sized vasculitis has remained challenging.

Notably, during the 1960s, after reporting TAO cases with visceral involvement as well as evidence of atherosclerotic lesions in visceral vessels from the autopsy of some TAO cases, TAO was considered as a type of atherosclerosis obliterans (ASO) with slow collateralization of the lesions and also the retrograde extension of the lesions from distal to proximal in comparison with usual cases of ASO. However, later, according to several studies on large series of TAO patients, the clinicopathological findings and angiography manifestation were considered characteristic for TAO as a separate disease from ASO or vasculitis [1].

Maybe, when we consider a young smoker with thrombophlebitis migrans and vascular involvement of infrapopliteal arteries and upper limbs, with normal blood sugar, normal lipid profile, and normal blood pressure, with typical skip lesions and corkscrew collaterals in angiography, the TAO diagnosis seems to be easy. However, there are several cases where the disease manifestation might be after 45 years, the patient might not be smoker, have dyslipidemia or glucose intolerance, or even high blood pressure without any atherosclerotic plaque, but at the same time present without obvious corkscrew collaterals $[27,28]$. Hence, the diagnosis of such cases as TAO would not be easy.

Up to now, TAO diagnosis is based on ruling out ASO and other types of vasculitis [4]. Usually, such investigations are not pathological studies only because tissue sampling on ischemic limbs are not practical. Therefore, biomarkers are usually investigated for ruling out ASO and other types of vasculitis.

However, inflammation, thrombosis, infection, and the presence of some autoantibodies are a part of the pathophysiology of TAO, ASO, and vasculitis and could be detected in patients with any of these diagnoses. Hence, for challenging cases like TAO clinical manifestation in older patients or non-smoker patients, these biomarkers might not be helpful but also making the diagnosis more complicated.

Although some biomarkers might be common in ASO, TAO, and vasculitis, each disease occurs through a different pathway with different origins. On the other hand, according to our current knowledge, there is no specific and definitive marker for differentiating TAO from atherosclerosis or vasculitis [9]. Hence, the mechanistic investigation of biomarkers is more useful and applicable.

Mechanistic investigations are a kind of fuzzy logic that demonstrate the concept of partial truth, where the truth value may range between completely true (one) and completely false (zero).

Based on this approach, there are three groups of markers: (1) similar markers, (2) controversial markers, (3) and differential markers.

\subsection{Similar Biomarkers}

Pro-inflammatory and cell-mediated immunity (CMI) cytokines, IL-33, HMGB1, neopterin, MMPs, ICAM1, complement components, fibrinogen, oxidative stress, NO 
levels, eNOS polymorphism, adrenalin and noradrenalin, lead, cadmium, and homocysteine are the common markers.

Thrombosis, inflammation, presence of autoantibodies, endothelial injury or dysfunction, vasoconstriction, high oxidative stress, and infection are common pathological pathways in these diseases. Similar markers are derived from these common pathways. For example, NO level is associated with vasoconstriction [146], pro-inflammatory and cellmediated immunity (CMI) cytokines, HMGB1, IL-33, neopterin, ICAM1, and complement components are most related to inflammation and infection [147-149]. Lead, cadmium, oxidative stress, and MMPs are related to cell damage [64,93]. Fibrinogen and homocysteine can be related to thrombosis $[111,119]$.

\subsection{Controversial Biomarkers}

The controversial markers are platelet and leukocyte count, haemoglobin, lipid profile, CRP, ESR, FBS, creatinine, d-dimer, hypercoagulation activity, protein C, and S. Many factors including family history and genetics, underlying medical conditions, environmental conditions, consumption of some drugs, and accompanying other diseases have effects on the levels of these markers. Therefore, these factors should be considered along with these conditions and the complete history of patients.

For example, although most TAO patients have normal FBS and do not have diabetes, they can still have these two conditions simultaneously. It has been reported that some clinicians rule out the several years' diagnosis of TAO because of high levels of FBS that recently occurred [26]. Even if the mechanism of disease decreases blood sugar and lipids, the basic levels of these molecules are different in each patient, depending on their genetic and history. Therefore, we see different levels of FBS and lipid profile in these patients $[20-23,27,28]$. These differences should not cause the early rule out of TAO diagnosis. In these cases, we should consider the whole data of each patient, including their signs and symptoms, pathology results, angiography, and other biomarker test results. For example, in the case of lipid profile, evaluation of TLR4 level, ox-LDL, and MDA can be helpful for the differentiation of TAO and atherosclerosis $[35,92,93]$.

Infection, some drugs, and underlying conditions can have effects on platelet and leukocyte count [150]. Therefore, all of these conditions should be considered case by case, personally.

Anaemia is one of the most controversial conditions in these diseases. Smoking can induce high levels of haemoglobin in smokers. However, in TAO patients, several cases of anaemia have been reported, and notably, the haemoglobin level is associated with the prognosis of TAO patients [10]. In atherosclerosis patients, anaemia is an independent risk factor for CVD outcomes [151]. In vasculitis, anaemia is a common condition that is more related to ANCA associated vasculitis (AAV) [152]. Therefore, it seems that the pathogenetic mechanisms of TAO and vasculitis can cause anaemia, while in atherosclerosis, anaemia is just an independent risk factor for CVD. These findings show that the underlying conditions unrelated to atherosclerosis are probably responsible for causing anaemia in atherosclerosis patients. Meanwhile, in TAO and vasculitis, anaemia should be considered in the context of these diseases as a part of them [9].

Different triggers, such as infection, inflammation pathways, and autoimmune responses, can induce elevated levels of CRP and ESR. These triggers usually are common in these three diseases, despite the origin, type, and pathway of them being specific in each disease. However, CRP and ESR do not have enough specificity for each pathway and are elevated in all of them, so we cannot recognize which one was responsible. Furthermore, some pain killers like NSAIDs (nonsteroidal anti-inflammatory drugs), usually taken by TAO patients, can influence the result of ESR [153].

In atherosclerosis, thrombosis is a consequence and product of the disease and happens suddenly as an event. Whilst in TAO and vasculitis, this is a part of pathogenesis and occurs consistently. As a marker that indicates the thrombosis and fibrinolysis situation, 
D-dimer has an elevated level in TAO and vasculitis consistently, while in atherosclerosis it rises during a thrombotic event [111].

\subsection{Differential Biomarkers}

Nitric oxide, MPV, TLRs, MDA, ox-LDL, sST2, antioxidant system, autoantibodies, and type of infection are differential markers.

Numerous studies show that although the diagnosis of TAO is ambiguous, despite the similarities, there are still significant differences between TAO, atherosclerosis, and vasculitis among laboratory markers that could be routinely effective in the differential diagnosis of TAO. Therefore, by examining these differences more closely, it is possible to design differential diagnostic panels and differentiate the TAO from atherosclerosis and vasculitis from the beginning of the patient's visit to the laboratory with the simplest, routine, and, of course, cheapest tests.

In general, our studies show that, for laboratory differential diagnosis between TAO and atherosclerosis or vasculitis, tests, such as CBC, Cholesterol, HDL and LDL, FBS, ANA, Anti-dsDNA, and Lupus anticoagulant, should be considered first. Then, in more advanced stages after the initial tests, more detailed diagnostic charts can be designed. In these charts, Anti-Cardiolipin (IgM class), Anti-beta2 (IgM class), ANCA, oral bacteria and rickettsia, oxLDL, and other mediators such as TLR4 can be tested. Evaluating ESR, CRP, or protein $\mathrm{C}$ and $\mathrm{S}$ is not recommended as diagnostic biomarkers for TAO (Tables 7 and 8 ).

Table 7. Routine laboratory differential diagnostic tests for TAO and Atherosclerosis.

\begin{tabular}{|c|c|c|}
\hline $\begin{array}{ll}\text { Disease } \\
\end{array}$ & TAO & Atherosclerosis \\
\hline Cholesterol & Normal to slightly high & High \\
\hline LDL & Normal to slightly high & High \\
\hline HDL & Low to Normal & Low \\
\hline FBS & Normal to slightly high & Normal to high (in diabetic patients) \\
\hline Anti-Cardiolipin & Positive (IgM class) & Negative \\
\hline Protc, prots & Normal & Prot $\mathrm{c}$ and prot $\mathrm{s}$ deficiency \\
\hline MPV & mostly Low & mostly High \\
\hline oxLDL & Normal & High \\
\hline Oral bacteria and rickettsial infection. & Positive & Negative for rickettsial infection \\
\hline TLR-2 and -4 & Low level of TLR4 & High level of TLR4 and TLR2 \\
\hline
\end{tabular}


Table 8. Routine laboratory differential diagnostic tests for TAO and Vasculitis.

\begin{tabular}{|c|c|c|}
\hline $\begin{array}{ll} & \text { Disease } \\
\end{array}$ & TAO & Vasculitis \\
\hline ESR & Controversial & High \\
\hline CRP & Controversial & High \\
\hline Anti-dsDNA, ANA & Negative & Positive \\
\hline Lupus anticoagulant & Negative & Positive \\
\hline Anti-Cardiolipin & Positive & Positive \\
\hline Anti-beta2 & Positive & Not reported \\
\hline ANCA & Negative & Positive \\
\hline Oral bacteria and rickettsial infection. & Positive & Positive for rickettsial infection \\
\hline Hypercoagulation activity & $\begin{array}{c}\text { Mostly considered as normal but } \\
\text { with increased risk with Factor V } \\
\text { Leiden mutation }\end{array}$ & $\begin{array}{c}\text { hypercoagulable states mostly } \\
\text { reported in Behçet syndrome and } \\
\text { AAV }\end{array}$ \\
\hline Platelet count & $\begin{array}{l}\text { Mostly normal; } \\
\text { (rarely high or low in specific } \\
\text { conditions) }\end{array}$ & thrombocytopenia \\
\hline Leukocyte count & Leukocytosis with neutrophilia & Leukopenia \\
\hline TLR & Low level of TLR4 & High level of TLR4 and TLR5 \\
\hline
\end{tabular}

\section{Conclusions}

Unfortunately, even after more than a century since Buerger first defined TAO, its diagnosis continues to be challenged. To date, no definitive biomarker points to a TAO diagnosis in patients with unusual manifestations of the disease or in patients with the risk factors of atherosclerosis or autoantibodies.

Until recently, the treatment of TAO has most often proceeded as a treatment for peripheral arterial disease rather than vasculitis. TAO patients usually undergo angiography to determine if they are eligible for angioplasty or bypass surgery, whilst the long-term outcomes of such procedures are unfavourable. At the same time, the outcomes of TAO patients who receive immunosuppressant medications, as in other types of vasculitis, are highly variable and typically unfavourable.

In this review, we noted both similarities and differences between TAO and atherosclerosis or vasculitis. These differences indicate that TAO is a disease entity distinct from peripheral arterial disease or vasculitis. In addition, the common biomarkers showed several common mechanisms in the development of TAO.

The tendency towards indistinctness regarding TAO may arise from the reductionism methodology favoured by researchers and the mechanistic thinking employed in the study of this disease. In addition, researchers tend to break down TAO into separate parts and topics for study without considering the aggregate interconnectedness of the disease as a whole. It is, after all, easy to lose sight of the whole when we focus our attention on individual parts. Achieving a holistic view of TAO instead of focusing on its dissimilarities to ASO or vasculitis can result in seeing the commonalities between TAO and other vascular diseases for a better understanding of this disease.

Author Contributions: Conceptualization, B.F., D.L., and F.M.; data curation, S.K., R.M., and H.S.; writing—original draft preparation, B.F., D.L., S.K., and H.S.; writing-review and editing, B.F., D.L., H.S., and F.M.; visualization of tables, B.F., D.L., R.M., S.K., and H.S.; revision and editing of tables, B.F., D.L., S.K., and H.S.; supervision, F.M. All authors have read and agreed to the published version of the manuscript.

Funding: This research received no external funding. 
Institutional Review Board Statement: Not applicable.

Informed Consent Statement: Not applicable.

Conflicts of Interest: The authors declare no conflict of interest.

\section{References}

1. Fazeli, B.; Rezaee, S.A. A review on Thromboangiitis obliterans pathophysiology: Thrombosis and angiitis, which is to blame? Vascular 2011, 19, 141-153. [CrossRef] [PubMed]

2. Mills, J.L., Sr. Buerger's disease in the 21st century: Diagnosis, clinical features, and therapy. In Seminars in Vascular Surgery; WB Saunders: Philadelphia, PA, USA, 2003; Volume 16, pp. 179-189.

3. Joviliano, E.E.; Dellalibera-Joviliano, R.; Dalio, M.; Evora, P.R.; Piccinato, C.E. Etiopathogenesis, clinical diagnosis and treatment of Thromboangiitis obliterans-Current practices. Int. J. Angiol. 2009, 18, 119-125. [CrossRef] [PubMed]

4. Shionoya, S. Diagnostic criteria of Buerger's disease. Int. J. Cardiol. 1998, 66 (Suppl. S1), S243-S245. [CrossRef]

5. Fazeli, B. Buerger's disease as an indicator of socioeconomic development in different societies, a cross-sectional descriptive study in the North-East of Iran. Arch. Med. Sci. 2010, 6, 343-347. [CrossRef] [PubMed]

6. Fazeli, B.; Ravari, H. Hyperhomocysteinemia as a consequence of life style among patients suffering from Thromboangiitis obliterans. Int. Angiol. 2013, 32, 442-443.

7. Zhou, J.; Austin, R.C. Contributions of hyperhomocysteinemia to atherosclerosis: Causal relationship and potential mechanisms. Biofactors 2009, 35, 120-129. [CrossRef]

8. Jorge, V.C.; Araújo, A.C.; Noronha, C.; Panarra, A.; Riso, N.; Vaz Riscado, M. Buerger's disease (Thromboangiitis obliterans): A diagnostic challenge. BMJ Case Rep. 2011, 2011, bcr0820114621. [CrossRef] [PubMed]

9. Fazeli, B.; Ravari, H. A disease-specific activity score for Thromboangiitis obliterans. Vascular 2014, 22, 336-340. [CrossRef]

10. Akbarin, M.M.; Ravari, H.; Rajabnejad, A.; Valizadeh, N.; Fazeli, B. Investigation of the Etiology of Anemia in Thromboangiitis Obliterans. Int. J. Angiol. 2016, 25, 153-158. [CrossRef]

11. Suresh, E. Diagnostic approach to patients with suspected vasculitis. Postgrad. Med. J. 2006, 82, 483-488. [CrossRef]

12. Kirkland, G.S.; Savige, J.; Wilson, D.; Heale, W.; Sinclair, R.A.; Hope, R.N. Classical polyarteritis nodosa and microscopic polyarteritis with medium vessel involvement-A comparison of the clinical and laboratory features. Clin. Nephrol. 1997, 47, 176-180.

13. Pietraszek, M.H.; Choudhury, N.A.; Koyano, K.; Sakaguchi, S.; Kamiya, T.; Urano, T.; Takada, Y.; Takada, A. Enhanced platelet response to serotonin in Buerger's disease. Thromb Res. 1990, 60, 241-246. [CrossRef]

14. Keramat, S.; Sadeghian, M.H.; Keramati, M.R.; Fazeli, B. Assessment of T helper 17-associated cytokines in thromboangiitis obliterans. J. Inflamm. Res. 2019, 12, 251-258. [CrossRef]

15. Murat, S.N.; Duran, M.; Kalay, N.; Gunebakmaz, O.; Akpek, M.; Doger, C.; Elcik, D.; Ocak, A.; Vatankulu, M.A.; Turfan, M.; et al. Relation between mean platelet volume and severity of atherosclerosis in patients with acute coronary syndromes. Angiology 2013, 64, 131-136. [CrossRef]

16. Ataş, H.; Canpolat, F.; Eskioglu, F. Evaluation of Mean Platelet Volume in Patients with Behcet's Disease as an Indicator of Vascular Thrombosis. Arch. Iran Med. 2018, 21, 234-239. [PubMed]

17. Khan, A.; Haider, I.; Ayub, M.; Khan, S. Mean Platelet Volume (MPV) as an indicator of disease activity and severity in lupus. F1000Res. 2017, 6, 126. [CrossRef]

18. Wessler, S. Thromboangiitis obliterans: Fact or fancy. Circulation 1961, 23, 165-167. [CrossRef] [PubMed]

19. Prusik, B.; Reinis, Z. Does Buerger's disease exist? Angiologica 1964, 1, 94-102. [CrossRef]

20. Jain, R.B.; Ducatman, A. Associations between smoking and lipid/lipoprotein concentrations among US adults aged $\geq 20$ years. J. Circ. Biomark. 2018, 7, 1849454418779310. [CrossRef] [PubMed]

21. Hus, I.; Sokolowska, B.; Walter-Croneck, A.; Chrapko, M.; Nowaczynska, A.; Dmoszynska, A. Assessment of plasma prothrombotic factors in patients with Buerger's disease. Blood Coagul. Fibrinolysis 2013, 24, 133-139. [CrossRef] [PubMed]

22. Ramin, M.; Salimi, J.; Meysamie, A. An Iranian scoring system for diagnosing Buerger's disease. Acta Med. Iran 2014, $52,60-65$.

23. Hewing, B.; Stangl, V.; Stangl, K.; Enke-Melzer, K.; Baumann, G.; Ludwig, A. Circulating angiogenic factors in patients with Thromboangiitis obliterans. PLoS ONE 2012, 7, e34717. [CrossRef] [PubMed]

24. Collens, W.S.; Wilensky, N.D. Thromboangiitis obliterans in a diabetic. Am. Heart J. 1939, 17, 624-627. [CrossRef]

25. Helm, S.; Horton, B. Thrombo-angiitis obliterans associated with diabetes mellitus. Ann. Intern. Med. 1939, 12, $1493-1498$.

26. Papa, M.Z.; Adar, R. A Critical Look at Thromboangiitis Obliterans (Buerger's disease). Perspect. Vasc. Surg. Endovasc. Ther. 1992, 5, 1-18. [CrossRef]

27. Igari, K.; Kudo, T.; Toyofuku, T.; Inoue, Y. Endothelial dysfunction in patients with Buerger disease. Vasc. Health Risk Manag. 2017, 13, 317-323. [CrossRef] [PubMed]

28. Fujii, Y.; Ohmura, Y.; Takeuchi, R.; Morimoto, S.; Uchida, H.; Hayashi, K.; Sano, S. Buerger's disease in a middle-aged woman with diabetes mellitus. A case report. Angiology 1996, 47, 97-102. [CrossRef] [PubMed]

29. Zannini, G.; Cotrufo, M. Epidemiological, angiographic and clinical aspects of Buerger's disease. J. Cardiovasc. Surg. 1973, 14, 17-20.

30. Sena, C.M.; Leandro, A.; Azul, L.; Seiça, R.; Perry, G. Vascular Oxidative Stress: Impact and Therapeutic Approaches. Front. Physiol. 2018, 9, 1668. [CrossRef] 
31. Marchio, P.; Guerra-Ojeda, S.; Vila, J.M.; Aldasoro, M.; Victor, V.M.; Mauricio, M.D. Targeting Early Atherosclerosis: A Focus on Oxidative Stress and Inflammation. Oxid. Med. Cell Longev. 2019, 2019, 8563845. [CrossRef]

32. Senoner, T.; Dichtl, W. Oxidative Stress in Cardiovascular Diseases: Still a Therapeutic Target? Nutrients 2019, 11, 2090. [CrossRef]

33. Ito, F.; Sono, Y.; Ito, T. Measurement and Clinical Significance of Lipid Peroxidation as a Biomarker of Oxidative Stress: Oxidative Stress in Diabetes, Atherosclerosis, and Chronic Inflammation. Antioxidants 2019, 8, 72. [CrossRef]

34. Alamdari, D.H.; Ravarit, H.; Tavallaie, S.; Fazeli, B. Oxidative and antioxidative pathways might contribute to Thromboangiitis obliterans pathophysiology. Vascular 2014, 22, 46-50. [CrossRef]

35. Sharebiani, H.; Fazeli, B.; Maniscalco, R.; Ligi, D.; Mannello, F. The Imbalance among Oxidative Biomarkers and Antioxidant Defense Systems in Thromboangiitis Obliterans (Winiwarter-Buerger Disease). J. Clin. Med. 2020, 9, 1036. [CrossRef] [PubMed]

36. Masoudian, M.; Fazeli, B.; Sharebiani, H.; Rajabnejad, A.; Ravari, H.; Akbarin, M.M.; Dadgarmoghaddam, M. Association of the five gene related endothelial cell dysfunction polymorphisms with Buerger's disease development. Int. Angiol. 2016, 35, $205-211$. [PubMed]

37. Muñoz-Sánchez, J.; Chánez-Cárdenas, M.E. A review on hemeoxygenase-2: Focus on cellular protection and oxygen response. Oxid Med Cell Longev. 2014, 2014, 604981. [CrossRef] [PubMed]

38. Cziráki, A.; Lenkey, Z.; Sulyok, E.; Szokodi, I.; Koller, A. L-Arginine-Nitric Oxide-Asymmetric Dimethylarginine Pathway and the Coronary Circulation: Translation of Basic Science Results to Clinical Practice. Front. Pharmacol. 2020, 11, 569914. [CrossRef]

39. Yeo, J.; Lee, Y.M.; Lee, J.; Park, D.; Kim, K.; Kim, J.; Park, J.; Kim, W.J. Nitric Oxide-Scavenging Nanogel for Treating Rheumatoid Arthritis. Nano Lett. 2019, 19, 6716-6724. [CrossRef]

40. Pan, L.; Yang, S.; Wang, J.; Xu, M.; Wang, S.; Yi, H. Inducible nitric oxide synthase and systemic lupus erythematosus: A systematic review and meta-analysis. BMC Immunol. 2020, 21, 10. [CrossRef]

41. İşcan, Y.; Yiğit, U.; Tuğcu, B.; Erdoğan, M.; Erdoğan, D.A.; Öner, V.; Taş, M.; Özyazgan, Y. Tear nitric oxide levels in Behçet's disease. Medicina 2012, 48, 559-562. [CrossRef]

42. da Silva, R.F.; Trapé, Á.A.; Reia, T.A.; Lacchini, R.; Oliveira-Paula, G.H.; Pinheiro, L.C.; Tanus-Santos, J.E.; Jacomini, A.M.; Bueno Júnior, C.R.; Zago, A.S. Association of endothelial nitric oxide synthase (eNOS) gene polymorphisms and physical fitness levels with plasma nitrite concentrations and arterial blood pressure values in older adults. PLoS ONE 2018, 13, e0206254. [CrossRef]

43. Lee, B.J.; Lin, Y.C.; Huang, Y.C.; Ko, Y.W.; Hsia, S.; Lin, P.T. The relationship between coenzyme Q10, oxidative stress, and antioxidant enzymes activities and coronary artery disease. Sci. World J. 2012, 2012, 792756. [CrossRef] [PubMed]

44. Christensen, L.L.; Selman, C.; Blount, J.D.; Pilkington, J.G.; Watt, K.A.; Pemberton, J.M.; Reid, J.M.; Nussey, D.H. Plasma markers of oxidative stress are uncorrelated in a wild mammal. Ecol. Evol. 2015, 5, 5096-5108. [CrossRef] [PubMed]

45. Peluso, I.; Palmery, M.; Drummen, G. Biomarkers of Oxidative Stress in Experimental Models and Human Studies with Nutraceuticals: Measurement, Interpretation, and Significance 2017. Oxid. Med. Cell Longev. 2017, 2017, 3457917. [CrossRef] [PubMed]

46. Arslan, C.; Altan, H.; Besirli, K.; Aydemir, B.; Kiziler, A.R.; Denli, S. The role of oxidative stress and antioxidant defenses in Buerger disease and atherosclerotic peripheral arterial occlusive disease. Ann. Vasc. Surg. 2010, 24, 455-460. [CrossRef] [PubMed]

47. Shruthi, S.; Thabah, M.M.; Zachariah, B.; Negi, V.S. Association of Oxidative Stress with Disease Activity and Damage in Systemic Lupus Erythematosus: A Cross Sectional Study from a Tertiary Care Centre in Southern India. Indian J. Clin. Biochem. 2021, 36, 185-193. [CrossRef] [PubMed]

48. Sam, N.B.; Li, B.Z.; Leng, R.X.; Pan, H.F.; Ye, D.Q. Circulating antioxidant levels in systemic lupus erythematosus patients: A systematic review and meta-analysis. Biomark. Med. 2019, 13, 1137-1152. [CrossRef]

49. Song, Y.R.; Kim, J.K.; Lee, H.S.; Kim, S.G.; Choi, E.K. Serum levels of protein carbonyl, a marker of oxidative stress, are associated with overhydration, sarcopenia and mortality in hemodialysis patients. BMC Nephrol. 2020, 21, 1-11. [CrossRef]

50. Shah, D.; Mahajan, N.; Sah, S.; Nath, S.K.; Paudyal, B. Oxidative stress and its biomarkers in systemic lupus erythematosus. J Biomed Sci. 2014, 21, 1-13. [CrossRef] [PubMed]

51. Zuzak, E.; Horecka, A.; Kiełczykowska, M.; Dudek, A.; Musik, I.; Kurzepa, J.; Kurzepa, J. Glutathione level and glutathione reductase activity in serum of coronary heart disease patients. J. Preclin. Clin. Res. 2017, 11, 103-105. [CrossRef]

52. Shah, D.; Sah, S.; Nath, S.K. Interaction between glutathione and apoptosis in systemic lupus erythematosus. Autoimmun. Rev. 2013, 12, 741-751. [CrossRef] [PubMed]

53. Senders, M.L.; Mulder, W.J.M. Targeting myeloperoxidase in inflammatory atherosclerosis. Eur Heart J 2018, 39, 3311-3313. [CrossRef] [PubMed]

54. Emmi, G.; Becatti, M.; Bettiol, A.; Hatemi, G.; Prisco, D.; Fiorillo, C. Behçet's Syndrome as a Model of Thrombo-Inflammation: The Role of Neutrophils. Front. Immunol. 2019, 10, 1085. [CrossRef] [PubMed]

55. Suárez-Rivero, J.M.; Pastor-Maldonado, C.J.; de la Mata, M.; Villanueva-Paz, M.; Povea-Cabello, S.; Álvarez-Córdoba, M.; Villalón-García, I.; Suárez-Carrillo, A.; Talaverón-Rey, M.; Munuera, M.; et al. Atherosclerosis and Coenzyme Q (10). Int. J. Mol. Sci. 2019, 20, 5195. [CrossRef]

56. Su, Y.J.; Cheng, T.T.; Chen, C.J.; Chiu, W.C.; Chang, W.N.; Tsai, N.W.; Kung, C.T.; Lin, W.C.; Huang, C.C.; Chang, Y.T.; et al. The association among antioxidant enzymes, autoantibodies, and disease severity score in systemic lupus erythematosus: Comparison of neuropsychiatric and nonneuropsychiatric groups. BioMed Res. Int. 2014, 2014, 137231. [CrossRef]

57. Cerne, D.; Kaplan-Pavlovcic, S.; Kranjec, I.; Jurgens, G. Mildly elevated serum creatinine concentration correlates with the extent of coronary atherosclerosis. Ren. Fail. 2000, 22, 799-808. [CrossRef] 
58. Yun, H.J.; Kim, D.I.; Lee, K.H.; Lim, S.J.; Hwang, W.M.; Yun, S.R.; Yoon, S.H. End stage renal disease caused by Thromboangiitis obliterans: A case report. J. Med. Case Rep. 2015, 9, 1-5. [CrossRef]

59. Shi, J.; Shen, Q.; Chen, X.M.; Du, X.G. Clinical characteristics and outcomes in microscopic polyangiitis patients with renal involvement: A study of 124 Chinese patients. BMC Nephrol. 2019, 20, 1-10. [CrossRef]

60. Roncon-Albuquerque, R.; Serrão, P.; Vale-Pereira, R.; Costa-Lima, J.; Roncon-Albuquerque, R., Jr. Plasma catecholamines in Buerger's disease: Effects of cigarette smoking and surgical sympathectomy. Eur. J. Vasc. Endovasc. Surg. 2002, 24, 338-343. [CrossRef]

61. Bauch, H.J.; Grünwald, J.; Vischer, P.; Gerlach, U.; Hauss, W.H. A possible role of catecholamines in atherogenesis and subsequent complications of atherosclerosis. Exp. Pathol. 1987, 31, 193-204. [CrossRef]

62. Sarathi, V.; Lila, A.R.; Bandgar, T.R.; Shah, N.S. Aortoarteritis: Could it be a form of catecholamine-induced vasculitis? Indian J. Endocrinol. Metab. 2013, 17, 163-166. [CrossRef]

63. Toutai, C.; Berrajaa, M.; Aissaoui, H.; Elouafi, N.; Jabi, R.; Bouziane, M.; Latrech, H.; Housni, B.; Ismaili, N. Rare association of aortoarteritis and pheochromocytoma: A case report. Int. J. Surg. Case Rep. 2020, 77, 91-95. [CrossRef]

64. Ali, H.; Khan, E.; Ilahi, I. Environmental Chemistry and Ecotoxicology of Hazardous Heavy Metals: Environmental Persistence, Toxicity, and Bioaccumulation. J. Chem. 2019, 2019, 6730305. [CrossRef]

65. Patwa, J.; Flora, S.J.S. Heavy Metal-Induced Cerebral Small Vessel Disease: Insights into Molecular Mechanisms and Possible Reversal Strategies. Int. J. Mol. Sci. 2020, 21, 3862. [CrossRef] [PubMed]

66. Mousazadeh, B.; Sharebiani, H.; Taheri, H.; Valizedeh, N.; Fazeli, B. Unexpected inflammation in the sympathetic ganglia in Thromboangiitis obliterans: More likely sterile or infectious induced inflammation? Clin. Mol. Allergy 2019, 17, 1-7. [CrossRef] [PubMed]

67. Harari, F.; Barregard, L.; Östling, G.; Sallsten, G.; Hedblad, B.; Forsgard, N.; Borné, Y.; Fagerberg, B.; Engström, G. Blood Lead Levels and Risk of Atherosclerosis in the Carotid Artery: Results from a Swedish Cohort. Environ. Health Perspect. 2019, 127, 127002. [CrossRef]

68. Tinkov, A.A.; Filippini, T.; Ajsuvakova, O.P.; Skalnaya, M.G.; Aaseth, J.; Bjørklund, G.; Gatiatulina, E.R.; Popova, E.V.; Nemereshina, O.N.; Huang, P.T.; et al. cadmium and atherosclerosis: A review of toxicological mechanisms and a meta-analysis of epidemiologic studies. Environ. Res. 2018, 162, 240-260. [CrossRef] [PubMed]

69. Alba, M.A.; Jennette, J.C.; Falk, R.J. Pathogenesis of ANCA-Associated Pulmonary Vasculitis. Semin. Respir. Crit. Care Med. 2018, 39, 413-424. [CrossRef] [PubMed]

70. Albert, D.; Clarkin, C.; Komoroski, J.; Brensinger, C.M.; Berlin, J.A. Wegener's granulomatosis: Possible role of environmental agents in its pathogenesis. Arthritis Rheum. 2004, 51, 656-664. [CrossRef] [PubMed]

71. Metryka, E.; Chibowska, K.; Gutowska, I.; Falkowska, A.; Kupnicka, P.; Barczak, K.; Chlubek, D.; Baranowska-Bosiacka, I. Lead $(\mathrm{Pb})$ Exposure Enhances Expression of Factors Associated with Inflammation. Int. J. Mol. Sci. 2018, 19, 1813. [CrossRef] [PubMed]

72. Bulmer, A.C.; Bakrania, B.; Du Toit, E.F.; Boon, A.C.; Clark, P.J.; Powell, L.W.; Wagner, K.H.; Headrick, J.P. Bilirubin acts as a multipotent guardian of cardiovascular integrity: More than just a radical idea. Am. J. Physiol. Heart Circ. Physiol. 2018, 315, H429-H447. [CrossRef] [PubMed]

73. Schwertner, H.A.; Jackson, W.G.; Tolan, G. Association of low serum concentration of bilirubin with increased risk of coronary artery disease. Clin. Chem. 1994, 40, 18-23. [CrossRef] [PubMed]

74. Suh, S.; Cho, Y.R.; Park, M.K.; Kim, D.K.; Cho, N.H.; Lee, M.K. Relationship between serum bilirubin levels and cardiovascular disease. PLoS ONE 2018, 13, e0193041. [CrossRef] [PubMed]

75. Chen, W.Q.; Dai, X.N.; Yu, Y.; Wang, Q.; Liang, J.Y.; Ke, Y.N.; Yi, C.H.; Lin, J. Analysis of clinical features and prognosis in patients with primary Sjögren's syndrome and autoimmune liver disease. J. Peking Univ. Health Sci. 2020, 52, 886-891.

76. Jäger, U.; Barcellini, W.; Broome, C.M.; Gertz, M.A.; Hill, A.; Hill, Q.A.; Jilma, B.; Kuter, D.J.; Michel, M.; Montillo, M.; et al. Diagnosis and treatment of autoimmune hemolytic anemia in adults: Recommendations from the First International Consensus Meeting. Blood Rev. 2020, 41, 100648. [CrossRef] [PubMed]

77. Tovoli, F.; Vannini, A.; Fusconi, M.; Frisoni, M.; Zauli, D. Autoimmune liver disorders and small-vessel vasculitis: Four case reports and review of the literature. Ann Hepatol. 2013, 13, 136-141. [CrossRef]

78. Koca, T.T. Clinical Significance of Serum Bilirubin in Behçet's Disease. J. Transl. Int. Med. 2018, 6, 185-188. [CrossRef] [PubMed]

79. Goh, G.B.; Pagadala, M.R.; Dasarathy, J.; Unalp-Arida, A.; Pai, R.K.; Yerian, L.; Khiyami, A.; Sourianarayanane, A.; Sargent, R.; Hawkins, C.; et al. Age impacts ability of aspartate-alanine aminotransferase ratio to predict advanced fibrosis in nonalcoholic Fatty liver disease. Dig. Dis. Sci. 2015, 60, 1825-1831. [CrossRef]

80. Lonardo, A.; Ballestri, S.; Guaraldi, G.; Nascimbeni, F.; Romagnoli, D.; Zona, S.; Targher, G. Fatty liver is associated with an increased risk of diabetes and cardiovascular disease-Evidence from three different disease models: NAFLD, HCV and HIV. World J. Gastroenterol. 2016, 22, 9674-9693. [CrossRef]

81. Olin, J.W. Thromboangiitis obliterans (Buerger's disease). New Engl. J. Med. 2000, 343, 864-869. [CrossRef]

82. Vijayakumar, A.; Tiwari, R.; Kumar Prabhuswamy, V. Thromboangiitis obliterans (Buerger's disease)-Current Practices. Int. J. Inflam. 2013, 2013, 156905. [CrossRef] [PubMed]

83. Dellalibera-Joviliano, R.; Joviliano, E.E.; Silva, J.S.; Evora, P.R. Activation of cytokines corroborate with development of inflammation and autoimmunity in Thromboangiitis obliterans patients. Clin. Exp. Immunol. 2012, 170, 28-35. [CrossRef] 
84. Wu, S.; Sun, X.; Wu, W.; Shi, D.; Jiang, T. Effect of revascularization on IL-6 and TNF- $\alpha$ in patients with Thromboangiitis obliterans. Exp. Ther. Med. 2018, 15, 3947-3951. [CrossRef] [PubMed]

85. Joras, M.; Poredos, P.; Fras, Z. Endothelial dysfunction in Buerger's disease and its relation to markers of inflammation. Eur. J. Clin. Invest. 2006, 36, 376-382. [CrossRef]

86. Slavov, E.S.; Stanilova, S.A.; Petkov, D.P.; Dobreva, Z.G. Cytokine production in Thromboangiitis obliterans patients: New evidence for an immune-mediated inflammatory disorder. Clin. Exp. Rheumatol. 2005, 23, 219-226.

87. Sharebiani, H.; Mohareri, M.; Mirhosseini, A.; Fazeli, B. The IL-33/sST2 Axis in Thromboangiitis obliterans. J. Inflamm. Res. 2020, 13, 317-323. [CrossRef] [PubMed]

88. Shapouri-Moghaddam, A.; Mohammadi, M.; Rahimi, H.R.; Esmaeili, H.; Mahmoudi, M.; Saeed Modaghegh, M.H.; Tavakol Afshari, J. The Association of HLA-A, B and DRB1 with Buerger's disease. Rep. Biochem. Mol. Biol. 2019, 8, 153-160. [PubMed]

89. Fehérvári, M.; Krepuska, M.; Széplaki, G.; Apor, A.; Sótonyi, P.; Prohászka, Z.; Acsády, G.; Szeberin, Z. The level of complement C3 is associated with the severity of atherosclerosis but not with arterial calcification in peripheral artery disease. Int. Angiol. 2014, 33, 35-41.

90. Omoyinmi, E.; Mohamoud, I.; Gilmour, K.; Brogan, P.A.; Eleftheriou, D. Cutaneous Vasculitis and Digital Ischaemia Caused by Heterozygous Gain-of-Function Mutation in C3. Front. Immunol. 2018, 9, 2524. [CrossRef]

91. Augusto, J.F.; Langs, V.; Demiselle, J.; Lavigne, C.; Brilland, B.; Duveau, A.; Poli, C.; Chevailler, A.; Croue, A.; Tollis, F.; et al. Low Serum Complement C3 Levels at Diagnosis of Renal ANCA-Associated Vasculitis Is Associated with Poor Prognosis. PLoS ONE 2016, 11, e0158871.

92. Mohareri, M.; Mirhosseini, A.; Mehraban, S.; Fazeli, B. Thromboangiitis obliterans episode: Autoimmune flare-up or reinfection? Vasc. Health Risk Manag. 2018, 14, 247-251. [CrossRef]

93. De Caridi, G.; Bitto, A.; Massara, M.; Pallio, G.; Pizzino, G.; Serra, R.; Altavilla, D.; Squadrito, F.; Spinelli, F. Increased Serum HMGB-1, ICAM-1 and Metalloproteinase-9 Levels in Buerger's Patients. Curr. Vasc. Pharmacol. 2016, 14, 382-387. [CrossRef]

94. Fazeli, B.; Rafatpanah, H.; Ravari, H.; Farid Hosseini, R.; Tavakol Afshari, J.; Hamidi Alamdari, D.; Valizadeh, N.; Moheghi, N.; Rezaee, S.A. Sera of patients with Thromboangiitis obliterans activated cultured human umbilical vein endothelial cells (HUVECs) and changed their adhesive properties. Int. J. Rheum. Dis. 2014, 17, 106-112. [CrossRef]

95. Wei, Z.; Jiang, W.; Wang, H.; Li, H.; Tang, B.; Liu, B.; Jiang, H.; Sun, X. The IL-6/STAT3 pathway regulates adhesion molecules and cytoskeleton of endothelial cells in Thromboangiitis obliterans. Cell. Signal. 2018, 44, 118-126. [CrossRef]

96. Olejarz, W.; Łacheta, D.; Kubiak-Tomaszewska, G. Matrix Metalloproteinases as Biomarkers of Atherosclerotic Plaque Instability. Int. J. Mol. Sci. 2020, 21, 3946. [CrossRef]

97. Pay, S.; Abbasov, T.; Erdem, H.; Musabak, U.; Simsek, I.; Pekel, A.; Akdogan, A.; Sengul, A.; Dinc, A. Serum MMP-2 and MMP-9 in patients with Behçet's disease: Do their higher levels correlate to vasculo-Behçet's disease associated with aneurysm formation? Clin. Exp. Rheumatol. 2007, 25, S70-S75.

98. Monach, P.A.; Warner, R.L.; Tomasson, G.; Specks, U.; Stone, J.H.; Ding, L.; Fervenza, F.C.; Fessler, B.J.; Hoffman, G.S.; Iklé, D.; et al. Serum proteins reflecting inflammation, injury and repair as biomarkers of disease activity in ANCA-associated vasculitis. Ann. Rheum. Dis. 2013, 72, 1342-1350. [CrossRef]

99. Piazza, G.; Creager, M.A. Thromboangiitis obliterans. Circulation 2010, 121, 1858-1861. [CrossRef]

100. Shapouri-Moghaddam, A.; Saeed Modaghegh, M.H.; Rahimi, H.R.; Ehteshamfar, S.M.; Tavakol Afshari, J. Molecular mechanisms regulating immune responses in Thromboangiitis obliterans: A comprehensive review. Iran J. Basic Med. Sci 2019, 22, 215-224. [PubMed]

101. Ketha, S.S.; Cooper, L.T. The role of autoimmunity in Thromboangiitis obliterans (Buerger's disease). Ann. N. Y. Acad. Sci. 2013, 1285, 15-25. [CrossRef]

102. Berlit, P.; Kessler, C.; Reuther, R.; Krause, K.H. New aspects of Thromboangiitis obliterans (von Winiwarter-Buerger's disease). Eur. Neurol. 1984, 23, 394-399. [CrossRef] [PubMed]

103. Halacheva, K.S.; Manolova, I.M.; Petkov, D.P.; Andreev, A.P. Study of anti-neutrophil cytoplasmic antibodies in patients with Thromboangiitis obliterans (Buerger's disease). Scand. J. Immunol. 1998, 48, 544-550.

104. Guo, Y.; Dai, Y.; Lai, J.; Fan, Y. Study about correlation of anti-neutrophil cytoplasmic antibodies and anticardiolipin antibodies with Thromboangiitis obliterans. Vascular 2013, 21, 363-368. [CrossRef]

105. Iwai, T.; Umeda, M.; Inoue, Y.; Dental University Buerger Disease Research Group. Pathogenic Mechanism of the Artery and the Vein in Buerger Disease: Our Hypothesis. Angiology 2014, 2, 1-4.

106. Chavoshan, A.; Sharebiani, H.; Taheri, H.; Fazeli, B. Antiphospholipid antibodies in Buerger's disease. Thromb. Res. 2019, 181, 64-66. [CrossRef]

107. Zhao, X.; Wen, Q.; Qiu, Y.; Huang, F. Clinical and pathological characteristics of ANA/anti-dsDNA positive patients with antineutrophil cytoplasmic autoantibody-associated vasculitis. Rheumatol. Int. 2021, 41, 455-462. [CrossRef]

108. Dinckal, M.H.; Ozkaynak, B.; Mert, B.; Sahin, I.; Sigirci, S.; Gulsen, K.; Ayca, B.; Okuyan, E. The relationship between antibeta 2 glycoprotein antibodies and SYNTAX score in patients undergoing coronary artery bypass graft surgery. Eur. Rev. Med. Pharmacol. Sci. 2014, 18, 2556-2561. [PubMed]

109. Legendre, P.; Régent, A.; Thiebault, M.; Mouthon, L. Anti-endothelial cell antibodies in vasculitis: A systematic review. Autoimmun. Rev. 2017, 16, 146-153. [CrossRef] [PubMed] 
110. Loeffen, R.; Spronk, H.M.; ten Cate, H. The impact of blood coagulability on atherosclerosis and cardiovascular disease. J. Thromb. Haemost. 2012, 10, 1207-1216. [CrossRef]

111. Undas, A.; Nowakowski, T.; Cieśla-Dul, M.; Sadowski, J. Abnormal plasma fibrin clot characteristics are associated with worse clinical outcome in patients with peripheral arterial disease and Thromboangiitis obliterans. Atherosclerosis 2011, 215, 481-486. [CrossRef]

112. Rivera-Chavarría, I.J.; Brenes-Gutiérrez, J.D. Thromboangiitis obliterans (Buerger's disease). Ann. Med. Surg. 2016, 7, 79-82. [CrossRef]

113. Raymackers, J.M.; Bosschaert, P. Cerebral venous thrombosis and Buerger's disease. Acta Neurol. Belg. 2014, 114, 139-140. [CrossRef] [PubMed]

114. Sato, T.; Tamai, H.; Kobayashi, M.; Yamamoto, K.; Komori, K. Immunohistochemical properties in the patients with Buerger's disease-possible role of plasminogen activator inhibitor-1 for preservation of vessel wall architecture. Cardiovasc. Pathol. 2011, 20, 266-271. [CrossRef]

115. Emmanuel, A.; Selvaraj, D.; Sen, I.; Agarwal, S.; Stephen, E.; Kota, A.; Nair, S.C.; Antoniswamy, B. D-dimer levels in patients with Thromboangiitis obliterans. Natl. Med. J. India 2019, 32, 134-136. [CrossRef] [PubMed]

116. Mensa, M.; Dobbs, T.; Jessop, Z.M.; Whitaker, I.S. Homozygous Factor V Leiden Thrombophilia in a Patient with Histologically Confirmed Thromboangiitis obliterans. Clin. Med. Insights Case Rep. 2019, 12, 1179547619828719. [CrossRef]

117. Avcu, F.; Akar, E.; Demirkiliç, U.; Yilmaz, E.; Akar, N.; Yalçin, A. The role of prothrombotic mutations in patients with Buerger's disease. Thromb. Res. 2000, 100, 143-147. [CrossRef]

118. Beigi, A.A.; Hoghoughi, M.A.; Eshaghian, A.; Zade, A.H.; Masoudpour, H. The role of folic acid on the hyperhomocysteinemia in the Buerger's disease (Thromboangiitis obliterans). J. Res. Med. Sci. 2014, 19, 1034-1037.

119. Barroso, M.; Handy, D.E.; Castro, R. The Link Between Hyperhomocysteinemia and Hypomethylation: Implications for Cardiovascular Disease. J. Inborn Errors Metab. Screen. 2017, 5, 2326409817698994. [CrossRef]

120. Stammler, F.; Diehm, C.; Hsu, E.; Stockinger, K.; Amendt, K. The prevalence of hyperhomocysteinemia in Thromboangiitis obliterans. Does homocysteine play a role pathogenetically? Dtsch. Med. Wochenschr. 1996, 121, 1417-1423. [CrossRef]

121. Birch, C.A. Buerger's disease. Leo Buerger (1879-1943). Practitioner 1973, 211, 823-824.

122. Gantcheva, M. The Significance of Anticardiolipin Antibodies in Patients with Vasculitis. Acta Morphol. et Anthropol. 2018, 25 , 38-43.

123. Batu, E.D. Neutrophil-mediated Thrombosis and NETosis in Behçet's Disease: A Hypothesis. J. Korean Med. Sci. 2020, 35 , e213. [CrossRef] [PubMed]

124. Borowiec, A.; Dąbrowski, R.; Kowalik, I.; Rusinowicz, T.; Hadzik-Błaszczyk, M.; Krupa, R.; Życińska, K. Elevated levels of $\mathrm{d}$-dimer are associated with inflammation and disease activity rather than risk of venous thromboembolism in patients with granulomatosis with polyangiitis in long term observation. Adv. Med. Sci. 2020, 65, 97-101. [CrossRef]

125. Piazzolla, G.; Candigliota, M.; Fanelli, M.; Castrovilli, A.; Berardi, E.; Antonica, G.; Battaglia, S.; Solfrizzi, V.; Sabbà, C.; Tortorella, C. Hyperhomocysteinemia is an independent risk factor of atherosclerosis in patients with metabolic syndrome. Diabetol. Metab. Syndr. 2019, 11, 1-9. [CrossRef] [PubMed]

126. Hamzaoui, A.; Harzallah, O.; Klii, R.; Mahjoub, S. Hyperhomocysteinaemia in Behçet's Disease. Biochem. Res. Int. 2010, 2010, 361387. [CrossRef] [PubMed]

127. Buerger, L. Is thromboangiitis an infectious disease? Surg. Gynecol. Obstet. 1914, 19, 582-588.

128. Iwai, T.; Inoue, Y.; Umeda, M.; Huang, Y.; Kurihara, N.; Koike, M.; Ishikawa, I. Oral bacteria in the occluded arteries of patients with Buerger disease. J. Vasc. Surg. 2005, 42, 107-115. [CrossRef]

129. Fazeli, B.; Mirhosseini, A.; Hashemi, Z.; Taheri, H. Detection of Rickettsia Endosymbiont Bemisia Tabaci in the Amputated Limbs of Three Buerger's disease Patients. Int. Med. Case Rep. J. 2020, 13, 33-40. [CrossRef]

130. Li, B.; Xia, Y.; Hu, B. Infection and atherosclerosis: TLR-dependent pathways. Cell. Mol. Life. Sci. 2020, 77, 2751-2769. [CrossRef]

131. C, B.R. Sample size considerations in genetic polymorphism studies. Hum. Hered. 2001, 52, 191-200.

132. McLoughlin, G.A.; Helsby, C.R.; Evans, C.C.; Chapman, D.M. Association of HLA-A9 and HLA-B5 with Buerger's disease. Br. Med. J. 1976, 2, 1165-1166. [CrossRef]

133. Aerbajinai, W.; Tsuchiya, T.; Kimura, A.; Yasukochi, Y.; Numano, F. HLA class II DNA typing in Buerger's disease. Int. J. Cardiol. 1996, 54, S197-S202. [CrossRef]

134. Tiwari, J.L.; Terasaki, P.I. HLA-DR and disease associations. Prog. Clin. Biol. Res. 1981, 58, 151-163.

135. Jaini, R.; Mandal, S.; Khazanchi, R.K.; Mehra, N.K. Immunogenetic analysis of Buerger's disease in India. Int. J. Cardiol. 1998, 66 (Suppl. S1), S283-S285. [CrossRef]

136. Numano, F.; Sasazuki, T.; Koyama, T.; Shimokado, K.; Takeda, Y.; Nishimura, Y.; Mutoh, M. HLA in Buerger's disease. Exp. Clin. Immunogenet. 1986, 3, 195-200.

137. Cao, Y.; Schmitz, J.L.; Yang, J.; Hogan, S.L.; Bunch, D.; Hu, Y.; Jennette, C.E.; Berg, E.A.; Arnett, F.C., Jr.; Jennette, J.C.; et al DRB1*15 allele is a risk factor for PR3-ANCA disease in African Americans. J. Am. Soc. Nephrol. 2011, 22, 1161-1167. [CrossRef]

138. Gonzalez-Gay, M.A.; Garcia-Porrua, C.; Hajeer, A.H.; Dababneh, A.; Ollier, W.E. HLA-DRB1*04 may be a marker of severity in giant cell arteritis. Ann. Rheum. Dis. 2000, 59, 574-575. [CrossRef]

139. Voskuyl, A.E.; Hazes, J.M.; Schreuder, G.M.; Schipper, R.F.; de Vries, R.R.; Breedveld, F.C. HLA-DRB1, DQA1, and DQB1 genotypes and risk of vasculitis in patients with rheumatoid arthritis. J. Rheumatol. 1997, 24, 852-855. 
140. Gorman, J.D.; David-Vaudey, E.; Pai, M.; Lum, R.F.; Criswell, L.A. Particular HLA-DRB1 shared epitope genotypes are strongly associated with rheumatoid vasculitis. Arthritis Rheum. 2004, 50, 3476-3484. [CrossRef]

141. Boechat Nde, O.; Ogusku, M.M.; Boechat, A.L.; Sadahiro, A. Interaction between smoking and HLA-DRB1*04 gene is associated with a high cardiovascular risk in Brazilian Amazon patients with rheumatoid arthritis. PLoS ONE 2012, 7, e41588. [CrossRef] [PubMed]

142. Glueck, C.J.; Haque, M.; Winarska, M.; Dharashivkar, S.; Fontaine, R.N.; Zhu, B.; Wang, P. Stromelysin-1 5A/6A and eNOS T-786C polymorphisms, MTHFR C677T and A1298C mutations, and cigarette-cannabis smoking: A pilot, hypothesis-generating study of gene-environment pathophysiological associations with Buerger's disease. Clin. Appl. Thromb. Hemost. 2006, 12, 427-439. [CrossRef]

143. Cheng, Y.; Xiong, M.; Liu, Y.; Tang, B. Lack of association between endothelial nitric oxide synthase gene polymorphisms with vasculitis: A meta-analysis. Clin. Exp. Rheumatol. 2015, 33, S107-S112.

144. Barbosa, A.M.; Silva, K.S.F.; Lagares, M.H.; Rodrigues, D.A.; da Costa, I.R.; Morais, M.P.; Martins, J.V.M.; Mascarenhas, R.S.; Campedelli, F.L.; Moura, K. Atherosclerosis: Analysis of the eNOS (T786C) gene polymorphism. Genet. Mol. Res. 2017, 16, gmr16039708. [CrossRef] [PubMed]

145. Kim, I.J.; Bae, J.; Lim, S.W.; Cha, D.H.; Cho, H.J.; Kim, S.; Yang, D.H.; Hwang, S.G.; Oh, D.; Kim, N.K. Influence of endothelial nitric oxide synthase gene polymorphisms $(-786 \mathrm{~T}>\mathrm{C}, 4 \mathrm{a} 4 \mathrm{~b}, 894 \mathrm{G}>\mathrm{T})$ in Korean patients with coronary artery disease. Thromb. Res. 2007, 119, 579-585. [CrossRef] [PubMed]

146. Pellegrino, D.; Sprovieri, E.; Mazza, R.; Randall, D.J.; Tota, B. Nitric oxide-cGMP-mediated vasoconstriction and effects of acetylcholine in the branchial circulation of the eel. Comp. Biochem. Physiol. A Mol. Integr. Physiol. 2002, 132, 447-457. [CrossRef]

147. Cicchese, J.M.; Evans, S.; Hult, C.; Joslyn, L.R.; Wessler, T.; Millar, J.A.; Marino, S.; Cilfone, N.A.; Mattila, J.T.; Linderman, J.J.; et al. Dynamic balance of pro- and anti-inflammatory signals controls disease and limits pathology. Immunol. Rev. 2018, 285, 147-167. [CrossRef]

148. Fillatreau, S. B cells and their cytokine activities implications in human diseases. Clin Immunol 2018, 186, 26-31. [CrossRef]

149. Lee, T.; Seo, J.W.; Sumpio, B.E.; Kim, S.J. Immunobiologic analysis of arterial tissue in Buerger's disease. Eur. J. Vasc. Endovasc. Surg. 2003, 25, 451-457. [CrossRef]

150. Junuzovic, D.; Zunic, L.; Dervisefendic, M.; Skopljak, A.; Pasagic, A.; Masic, I. The toxic effect on leukocyte lineage of antimicrobial therapy in urinary and respiratory infections. Med. Arh. 2014, 68, 167-169. [CrossRef] [PubMed]

151. Sarnak, M.J.; Tighiouart, H.; Manjunath, G.; MacLeod, B.; Griffith, J.; Salem, D.; Levey, A.S. Anemia as a risk factor for cardiovascular disease in The Atherosclerosis Risk in Communities (ARIC) study. J. Am. Coll. Cardiol. 2002, 40, 27-33. [CrossRef]

152. Kawamura, T.; Usui, J.; Kaneko, S.; Tsunoda, R.; Imai, E.; Kai, H.; Morito, N.; Saito, C.; Nagata, M.; Yamagata, K. Anaemia is an essential complication of ANCA-associated renal vasculitis: A single center cohort study. BMC Nephrol. 2017, 18, 1-8. [CrossRef] [PubMed]

153. Hegg, R.; Lee, A.G.; Tagg, N.T.; Zimmerman, M.B. Statin or nonsteroidal anti-inflammatory drug use is associated with lower erythrocyte sedimentation rate in patients with giant cell arteritis. J. Neuroophthalmol. 2011, 31, 135-138. [CrossRef] [PubMed] 